\title{
Herbal Drugs in Chronic Fatigue Syndrome: An Overview
}

\author{
Ajay Semalty ${ }^{a}$ Mona Semalty $^{a} \quad$ Vandana S. Panda $^{b}$ Kirtika H. Asranib Hardik D. Ashar ${ }^{b}$ \\ a'Department of Pharmaceutical Sciences, H.N.B. Garhwal (Central) University, Srinagar, Garhwal, \\ ${ }^{b}$ Department of Pharmacology and Toxicology, Prin. K.M. Kundnani College of Pharmacy, Colaba, Mumbai, India
}

\section{Keywords}

Chronic fatigue syndrome $\cdot$ Fatigue $\cdot$ Herbal drugs

\section{Summary}

Chronic fatigue syndrome (CFS) is a debilitating and complex disorder characterized by profound fatigue of 6 months or longer duration that is not improved by bed rest and that may be worsened by physical or mental activity. It is often age-related and may coexist with other diseases such as multiple sclerosis, Parkinson's disease, depression, cancer, HIV infection etc. Persons with CFS most often function at a substantially lower level of activity than they were capable of before the onset of illness. Modern medicine has limited therapies and those offered by it have strong side-effects. On the other hand, various traditional systems of medicine such as the Chinese herbal system and Ayurveda offer several botanicals, especially the adaptogens, which have been used to combat chronic fatigue effectively. Literature reports a plethora of animal and clinical studies on the safety and efficacy of these plant drugs. The present article extensively reviews CFS, its pathophysiology, and its pharmacological treatment, with a special emphasis on herbal drugs such as Cat's claw, Ginseng, caterpillar fungus, ashwagandha, Tulsi, jiaogulan etc. The botanical therapies discussed here are very commonly used drugs with profound data available on them.

\section{Schlüsselwörter}

Chronisches Müdigkeitssyndrom · Müdigkeit · Pflanzliche Drogen

\section{Zusammenfassung}

Pflanzliche Drogen bei Chronischem Müdigkeitssyndrom: Eine Übersicht Das Chronische Müdigkeitssyndrom (CFS) ist eine schwächende und komplexe Erkrankung, die durch umfassende Müdigkeitserscheinungen von 6 Monaten oder längerer Dauer, die nicht durch Bettruhe gebessert bzw. durch körperliche oder geistige Aktivität verschlechtert werden kann, gekennzeichnet ist. Dies erfolgt zumeist altersbedingt und kann gemeinsam mit anderen Krankheiten wie Multiple Sklerose,
Morbus Parkinson, Depression, Krebs, HIV-Infektion usw. auftreten. Menschen mit CFS weisen zumeist ein deutlich geringeres Level an Aktivität auf, als ihnen noch vor Beginn der Krankheit möglich war. Die moderne Medizin wartet mit einer begrenzten Anzahl an Therapien auf, die zudem starke Nebenwirkungen mit sich bringen. Dahingegen bieten verschiedene traditionelle Medizinsysteme, wie die chinesische Kräuterheilkunde und Ayurveda, eine Anzahl pflanzlicher Stoffe - und hier vor allem die Adaptogene - an, die eingesetzt worden sind, um chronische Müdigkeit effektiv zu bekämpfen. Die Literatur bietet eine Fülle von Tier- sowie klinischen Studien, die die Sicherheit und Wirksamkeit dieser pflanzlichen Drogen belegen. Der vorliegende Beitrag behandelt ausführlich das CFS, seine Pathophysiologie und seine pharmakologischen Behandlungsmöglichkeiten, wobei besonderes Augenmerk auf pflanzliche Drogen wie Katzenkralle, Ginseng, Raupenpilz, Ashwagandha, Tulsi, Jiaogulan usw. gelegt wird. Die in diesem Rahmen diskutierten pflanzlichen Therapien stellen sehr häufig eingesetzte Medikamente dar, zu denen umfassende Daten verfügbar sind.

\section{Mots-clés}

Syndrome de fatigue chronique · Fatigue · Plantes médicinales

\section{Résumé}

Les plantes médicinales dans le traitement du syndrome de fatigue chronique: aperçu

Le syndrome de fatigue chronique (SFC) est un trouble complexe et invalidant. II se caractérise par une profonde fatigue sur une durée d'au moins 6 mois, qui ne s'améliore pas avec le repos et peut s'aggraver avec l'activité physique ou mentale. II est souvent lié à l'âge et peut coexister avec d'autres maladies telles que la sclérose en plaques, la maladie de Parkinson, la dépression, le cancer, l'infection par le VIH, etc. La plupart du temps, les personnes atteintes du SFC présentent un niveau d'activité bien moindre à celui qu'elles étaient capables d'entretenir avant l'apparition de la maladie. Les traitements proposés par la médecine moderne sont limités et sont associés à d'importants effets indésirables. Plusieurs formes de médecine traditionnelle, comme l'herboristerie chinoise et l'āyurveda, offrent en revanche un

$\begin{array}{ll}\text { KARGER } & \begin{array}{l}\text { @ 2012 S. Karger GmbH, Freiburg } \\ 1015-0684 / 12 / 0243-0155 \$ 38.00 / 0\end{array} \\ \begin{array}{l}\text { Fax }+497614520714 \\ \text { Information@Karger.de } \\ \text { www.karger.com }\end{array} & \begin{array}{l}\text { Accessible online at: } \\ \text { www.karger.com/szg }\end{array}\end{array}$

Dr. Vandana Sanjeev Panda

Department of Pharmacology and Toxicology, Prin. K.M. Kundnani College of Pharmacy Jote Joy Building, Rambhau, Salgaonkar Marg, Cuffe Parade

Colaba, Mumbai 400005, India

Tel. +91 22-22164368, Fax -22165272

vspanda@rediffmail.com 
large choix de préparations à base de plantes, en particulier les adaptogènes, pour combattre efficacement le syndrome de fatigue chronique. La littérature scientifique regorge d'études cliniques et menées chez l'animal sur la sécurité et l'efficacité de ces traitements à base de plantes. Le présent article propose une étude approfondie du SFC, de sa physiopathologie, ainsi que de son traitement pharmacologique, avec un accent particulier sur les plantes médicinales telles que la liane du pérou, le ginseng, le «champignon chenille», l'ashwagandha, le tulsi, le jiaogulan, etc. Les traitements à base de plantes dont il est question ici sont utilisés très couramment et leur utilisation est très largement documentée.

\section{Introduction}

The stressful human lifestyle of the 21st century has given rise to a wide variety of lifestyle diseases like alopecia, obesity, hypertension and fatigue. Chronic fatigue syndrome (CFS), also referred to as Royal Free disease, Iceland disease, neurasthenia, myalgic encephalomyelitis (ME), chronic fatigue and immune dysfunction syndrome (CFIDS), and post-viral fatigue syndrome, is a heterogeneous disorder which is found in all racial, ethnic and socioeconomic populations and can be as debilitating as multiple sclerosis and chronic obstructive lung disease [1]. CFS is a relatively common medical condition that affects over 800,000 Americans at any given time, or approximately 1 in 544 or $0.18 \%$ of the US population. It appears to affect nearly twice as many women than men (522 vs. 291 per 100,000) [2, 3]. The United States Centers for Disease Control and Prevention (CDC) coined the name of the disease and developed a case definition of CFS. This case definition was created primarily to standardize the patient population for research studies [4].

A 1994 revision of the CDC case definition constitutes the current criteria for CFS and the most widely used definition internationally [5]. According to this definition, CFS is an illness characterized by a disabling and persistent fatigue (of at least 6 months) that substantially reduces the person's level of activity. In addition, four or more of the following symptoms must occur with fatigue in a 6-month period: impaired memory or concentration, sore throat, tender glands, aching or stiff muscles, multi-joint pain, new headaches, unrefreshing sleep, and post-exertional fatigue.

The present article reviews CFS as well as its various aspects, causes, and treatment with an emphasis on herbal remedies.

\section{Epidemiology}

CFS is not only a vastly complex illness but also one that is escalating alarmingly in frequency. Epidemiological stud- ies confirm that it is spreading and crossing all boundaries, including socio-economic, racial, political, gender, occupational and geographical categories. Estimates of the prevalence of CFS have varied depending on the type of population surveyed, on the study methods, and on which definition was used [6]. Current estimates for the prevalence of CFS range from 0.007 to $2.8 \%$ in the general adult population and from 0.006 to $3.0 \%$ in primary care or general practice [7]. CFS also occurs in children and adolescents but apparently at a lower rate [8]. Early reports from tertiary clinics suggested that CFS affected primarily young, white, successful women [9]. Most persons who are diagnosed with CFS are 30-40 years of age, and most surveys support a female preponderance. However, community surveys have found that white individuals have a lower risk of CFS compared with Latinos, African Americans, and Native Americans [10].

\section{Causes of Chronic Fatigue Syndrome}

CFS has many distinct purported causes ranging from viral infection (Epstein-Barr virus (EBV), human herpes virus 6 , and others) to bacterial infection (Giardia lamblia, Borrelia burgdorferi) to various immunologic abnormalities such as decreased natural killer cell activity and altered helper/suppressor T-cell ratios (table 1).

CFS occurs due to a variety of causes; prominent among them are sedentary lifestyles, poor eating and sleeping habits, stress, and a hyper-competitive workplace atmosphere. It also leads to a host of other problems such as insomnia and other psychological as well as neurological problems [11]. In fact, there is still widespread debate whether chronic fatigue is a psychological disorder or whether it is neurological in nature. Experts, however, are of the opinion that the treatment of the disease should be a combination of both psychotherapy and phytotherapy.

A recent study forecasts that $40-45 \%$ of the entire working population of the USA will be affected by the problem of fatigue by 2025 because of increasing working hours. CFS is also reported to be associated with Parkinson's disease, multiple sclerosis, amyotrophic lateral sclerosis, aging, depression, cancer, and HIV infection [12-18].

\section{Pathophysiology}

The functional changes taking place in CFS involve alterations in the central nervous system (CNS), serotonergic system, hypothalamic-pituitary-adrenal (HPA) axis, immune system, and genetics.

\section{Altered CNS}

Neuroimaging studies revealed some structural and functional alterations of the CNS among CFS patients. Two 
Table 1. Overview of the potential causes of chronic fatigue

\begin{tabular}{|c|}
\hline $\begin{array}{l}\text { Acute or chronic infections } \\
\text { Viral } \\
\text { Bacterial } \\
\text { Parasitic } \\
\text { Zoonotic } \\
\end{array}$ \\
\hline Mood disorders \\
\hline Sleep disturbances inclusive of sleep apnoea \\
\hline Malignancy of any origin \\
\hline $\begin{array}{l}\text { Cardiovascular disorders/conditions } \\
\text { Agranulocytosis } \\
\text { Anaemia } \\
\text { Cardiac failure } \\
\text { Congenital heart disease } \\
\text { Cor pulmonale } \\
\text { Endocarditis } \\
\text { Subacute bacterial endocarditis } \\
\text { Leukaemia } \\
\text { Mitral stenosis } \\
\text { Myocarditis } \\
\text { Thalassaemia major or minor }\end{array}$ \\
\hline $\begin{array}{l}\text { Metabolic disorders/conditions } \\
\text { Avitaminosis } \\
\text { Diabetes mellitus } \\
\text { Electrolyte disturbances } \\
\text { Hyperparathyroidism } \\
\text { Hypothyroidism } \\
\text { Hyperthyroidism } \\
\text { Euthyroid sick syndrome } \\
\text { Menopause } \\
\text { Metabolic disorders } \\
\text { Phenylketonuria } \\
\text { Fanconi syndrome } \\
\text { Cystic fibrosis }\end{array}$ \\
\hline $\begin{array}{l}\text { Endocrine disorders/conditions } \\
\text { Acromegaly } \\
\text { Addison's disease } \\
\text { Hypopituitarism } \\
\end{array}$ \\
\hline $\begin{array}{l}\text { Connective tissue diseases } \\
\text { Rheumatoid arthritis } \\
\text { Lupus } \\
\text { Scleroderma }\end{array}$ \\
\hline Chronic allergy reactions \\
\hline Heavy metal poisoning (e.g. lead, mercury, arsenic) \\
\hline $\begin{array}{l}\text { Other } \\
\text { Cushing syndrome } \\
\text { Myelodysplastic syndrome } \\
\text { Sick building syndrome } \\
\text { Post-polio syndrome } \\
\text { Temporal arteritis } \\
\text { Ulcerative colitis } \\
\text { Malabsorption syndromes } \\
\text { Hodgkin's disease } \\
\text { Cerebrovascular accident } \\
\text { Head injury } \\
\text { Multiple sclerosis } \\
\text { Myasthenia gravis } \\
\text { Myelofibrosis } \\
\text { Osteomalacia and rickets } \\
\text { Parkinson's disease } \\
\text { Polycythaemia (rubra) vera } \\
\text { Polymyalgia rheumatica } \\
\text { Polyneuritis } \\
\text { Rheumatic fever } \\
\text { Cirrhosis/Uraemia }\end{array}$ \\
\hline
\end{tabular}

separate cohorts of CFS patients showed a marked decline in grey matter volume compared with matched healthy controls, and this reduction was associated with the objectively measured decline in physical activity [19]. Subjective cognitive impairment, more specifically informationprocessing dysfunction among CFS patients, was linked to the objective findings by functional magnetic resonance imaging (fMRI), which corresponds to an increased neural resource allocation [20]. Another fMRI study [21] suggested that CFS might be associated with dysfunctional motor planning. Two neurophysiologic studies $[22,23]$ also showed altered CNS functioning during motor activities with muscle contraction.

\section{Serotonergic System}

Most of the existing evidence has suggested a hyperserotonergic state or upregulated serotonin receptors among CFS patients, in contrast to the hyposerotonergic state seen in major depression, although this has mainly been indirect evidence from neuroendocrine challenge studies. Two published studies have now measured the status of cerebral serotonin receptors in CFS directly. In the first, Cleare et al. [24] showed decreased 5-HT1A receptor binding throughout the brain using positron emission tomography (PET), the reduction being most marked in the hippocampi bilaterally. The authors noted that it is possible that 5-HT1A receptor downregulation is a response to increased levels of synaptic serotonin, but also noted alternative explanations. For example, although Cleare et al. studied only nondepressed CFS patients, patients who do have depression show downregulation of 5-HT1A receptors even after treatment; since many CFS sufferers (including most of those studied by Cleare et al.) have a past history of depression, this is one possible explanation. Similarly, the effect on the serotonin system of the behavioural consequences of CFS (such as sleep disturbance and inactivity) remains unclear. In a second PET study in non-depressed CFS subjects, Yamamoto et al. [25] found reduced 5-HT1A receptor binding in the rostral anterior cingulate of CFS patients, which correlated inversely with the level of reported pain (i.e. lower binding was related to higher pain scores) but not to other symptoms. These authors also pointed out that the reduced serotonin reported could be secondary to increased serotonin synaptic levels or to changes in blood flow or neuronal density in these areas.

\section{HPA Axis Abnormalities}

Some of the most robust findings concerning the pathophysiology of CFS have been related to the HPA axis, with much evidence supporting mild HPA axis hypoactivity [26]. Recently published studies have provided further support for disruption to the HPA axis. Two studies [27, 28] have bridged a longstanding gap in the literature regarding regular blood sampling of adrenocorticotropic hormone (ACTH) and cortisol throughout an entire 24-h 
circadian period. Both studies found underactivity of the HPA axis in the early morning in CFS, apparent in ACTH levels in one study and cortisol levels in the other. Further support that the HPA axis is under-responsive to direct stimulus came from two papers $[29,30]$, one measuring the cortisol response to awakening and the other the ACTH response to hypoglycaemia, with the latter study also finding a correlation with symptom duration and severity. The finding that the more pronounced the HPA axis changes, the longer the CFS, supports the latter assertion [30]. Furthermore, two prospective studies of groups at high risk of developing chronic fatigue (post-EBV infection and post-surgery) found that the development of fatigue 6 months after was not associated with any HPA axis changes [31,32]. However, one study [33] suggested the opposite, showing that a subset of healthy regular exercisers developed pain and fatigue after being experimentally deprived of exercise for 1 week, and these individuals had lower HPA axis function at the baseline of the experiment. In other words, a subset of healthy individuals in the general population may have altered the HPA axis function, which might subsequently render them vulnerable to developing fatigue.

\section{Immune Dysfunction}

CFS has been associated with changes in the immune system, especially with immune activation and perturbation in T-cell and natural killer cell count and functions. Cytokines, major cell products reflecting immune cell function, were also suggested to play a role in the pathogenesis and clinical manifestation of CFS. Many studies measured various cytokines, mainly concentrating on proinflammatory ones such as TNF- $\alpha$, IL-1, and IL- 6 as these are known to be involved in the regulation of the HPA and sympathetic nervous system, but the results were contradictory [34]. A recent study [35] demonstrated diminished levels of mRNA and protein production for transforming growth factor beta 1 (TGFb1) in CFS subjects when compared with healthy controls. TGFbl, as a major regulatory cytokine, is involved in suppressing the immune system especially via inhibition of antibody production. Deficiency of TGFb1 in CFS subjects may contribute to symptoms such as myalgia and muscular fatigue [35]. It is possible that TGFbl could be an indicator of treatment response in CFS; however, other studies that fail to find any differences in the TGFbl level in CFS patients suggest caution. A recent proposal explored for CFS is the Th1/Th2 paradigm of immune-mediated diseases [36]. One of the main supporting arguments is the frequent reporting of natural killer cell activity reduction in CFS [37]. Natural killer cells play a key role in the generation of Th1-type antiviral responses. Loss of their activity could result in a Th2 bias, persistent viral activation, and finally chronic infection. Another argument supporting the involvement of the immune system in the pathogenesis of CFS is the communication between the HPA axis and the immune system via glucocorticoids. They can modulate immune responses by inhibiting the production of proinflammatory cytokines, therefore promoting the switch from Th1type towards Th2-type responses, which is in agreement with the study by Skowera et al. [38]. Several studies investigated immune responses during and after stress as it is well known that stress and exercise can substantially exacerbate fatigue in CFS patients [39].

\section{Genetics}

Genetic studies on CFS are not many to date, but there is some evidence of CFS being a moderately heritable condition from several studies [40,41]. A number of studies on gene expression in peripheral blood mononuclear cells presented some apparently interesting findings indicating that several genes are possibly involved in the pathogenesis of CFS [42]. Two studies [43, 44] reported the involvement of the serotonin transporter gene and the angiotensin-converting enzyme gene, the latter being associated with muscle metabolism and physical endurance. Theoretically, in order to realistically detect small genotypic relative risks, large samples are required. Hence, these findings should again be replicated further, ideally by large association studies with correct candidate genes.

\section{Treatment}

Unclear aetiology, diagnostic uncertainty, and the resultant heterogeneity of the CFS population make it difficult to establish fixed treatment recommendations for CFS. Various treatment studies have evaluated immunological substances, pharmacological products, nutritional supplements, physical therapies, and multidimensional treatments [11]. With the exception of findings for physical and multidimensional treatments (i.e. behavioral interventions), the results of these controlled treatment studies have been negative or inconclusive.

\section{Pharmacological Treatments}

With the exception of one placebo-controlled trial of immunoglobulin $\mathrm{G}$ (IgG) [45] and a randomized, placebocontrolled, double-blind study [46] of a ribonucleic acid, immunological and antiviral substances have not been shown to be effective in the treatment of fatigue and other symptoms in CFS. Major pharmacological therapies for treating CFS (table 2) can be classified as antidepressant therapy, steroid therapy, immunotherapy, nutrient therapy, and nicotinamide adenine dinucleotide therapy. The most common drugs prescribed by physicians for the treatment of CFS (table 3) are sedatives, anticonvulsants, stimulants, muscle relaxants, antidepressants, analgesics etc. 
Table 2. Major pharmacological therapies for treatment of CFS

\begin{tabular}{|c|c|c|}
\hline Therapy & Therapeutic effect & Side-effects \\
\hline Anti-depressant therapy & no beneficial effect & $\begin{array}{l}>15 \% \text { of the patients with certain side-effects such as gastrointestinal } \\
\text { complaints, headache, and anxiety }\end{array}$ \\
\hline Steroid therapy & $\begin{array}{l}\text { short term benefits with low doses for hypoactivity } \\
\text { of the HPA axis but no effect after withdrawal }\end{array}$ & $\begin{array}{l}\text { high doses associated with significant side-effects such as Cushing's } \\
\text { syndrome, ulcers, acne, osteopenia, immunosuprresion, etc. }\end{array}$ \\
\hline Immunotherapy & $\begin{array}{l}\text { intravenous immunoglobin therapy effectively } \\
\text { relieves symptoms for CFS following an acute } \\
\text { viral infection, while another study found no effect }\end{array}$ & $\begin{array}{l}\text { of the subjects, } 82 \% \text { treated with IgG have intense side-effects such } \\
\text { as gastrointestinal complaints, headache, anthralgia, and sometimes } \\
\text { worst fatigue }\end{array}$ \\
\hline Nutritional supplements & benefits from nutritional supplements & no side-effects reported \\
\hline NADH therapy & $\begin{array}{l}\text { efficacy observed only during the first trimester } \\
\text { of the trial }\end{array}$ & $\begin{array}{l}\text { no severe adverse effects but mild effects included poor appetite, } \\
\text { dyspepsia, and abdominal distention }\end{array}$ \\
\hline
\end{tabular}

Table 3. Most common drugs prescribed for treatment of CFS

\begin{tabular}{|c|c|}
\hline Class of drug & Drug name \\
\hline \multicolumn{2}{|l|}{ Sleep improvement } \\
\hline Sleep initiators & alprazolam, temazepam, clonazepam \\
\hline Sleep sustainers & amitriptyline, doxepin, trazodone, \\
\hline & mirtazapine, gabapentin, tizanidine \\
\hline Sleep initiators and sustainers & zolpidem, zaleplon, eszopiclone, estazolam \\
\hline Anticonvulsants (used in CFS as mood stabilizers or for pain relief and sleep) & lamotrigine, divalproex sodium, gabapentin, topiramate, pregabalin \\
\hline Stimulants (used in CFS for wakefulness and mental acuity) & modafinil, amphetamine salts, \\
\hline Muscle relaxants (used in CFS for pain and sleep) & $\begin{array}{l}\text { methylphenidate, atomoxetine, sodium oxybate } \\
\text { cyclobenzaprine, metaxalone, methocarbamol, orphenadrine, tizandine }\end{array}$ \\
\hline \multicolumn{2}{|l|}{ Antidepressants } \\
\hline SSRI class of antidepressants & $\begin{array}{l}\text { fluoxetine, sertraline, paroxetine, } \\
\text { citalopram, escitalopram }\end{array}$ \\
\hline SNRI class of antidepressants & venlafaxine, duloxetine, buproprion \\
\hline $\begin{array}{l}\text { Tricyclic class of antidepressants (treats multiple symptoms; } \\
\text { may help with mood, sleep, and pain) }\end{array}$ & amitriptyline, doxepin, desipramine \\
\hline Receptor antagonist class of antidepressants & trazodone, mirtazapine \\
\hline \multicolumn{2}{|l|}{ Analgesics (pain relief) } \\
\hline Nonsteroidal anti-inflammatory & ibuprofen, naproxen, meloxicam \\
\hline Cox II inhibitors & celecoxib \\
\hline Analgesics & acetaminophen \\
\hline Short-acting narcotics/opiates & propoxyphene \\
\hline Long-acting narcotics/opiates & morphine sulfate, morphine sulfate, morphine sulfate, fentanyl \\
\hline Narcotic-like analgesics & tramadol \\
\hline Topical & lidocaine \\
\hline
\end{tabular}

Non-Pharmacological and Behavioural Interventions

Non-pharmacological treatments, specifically graded exercise programmes and cognitive behaviour therapy have shown promise in improving the outcome of CFS.

\section{Herbal Drugs in Chronic Fatigue Syndrome}

Herbal drugs are increasingly gaining worldwide acceptance from public and medical professionals due to greater advances in the understanding of the mechanisms by which herbs positively influence health and quality of life [47]. A mong the various classes of herbal drugs, adaptogens are described as the best choice. The concept of an 'adaptogen' is relatively new. Remedies for this impairment are commonly found in traditional Chinese (Qi tonic), African
(Manyasi), Tibetan, Ayurvedic (Rasayana), and Cherokee medicine [48, 49]. Adaptogenic herbal drugs have the distinct ability to increase the body's resistance to stress resulting from physical, biological, and chemical factors. A person with CFS is under a large amount of stress not only from the causes of the syndrome but also from a decreased quality of life and health. This kind of stress produces systemic effects such as increased levels of stressrelated hormones (cortisol), resulting in a decline in immunologic functions (decreased natural killer cell effectiveness and secretory IgA levels in the gut) that predispose the body to additional health decline. When exposed to a stressor, the human body reacts in a relatively predetermined manner by producing hormonal changes as dictated by the CNS via the HPA axis. Stress results in increased cortisol levels concomitant with a decrease in 
negative feedback downregulation (thereby allowing the body to temper an increase in this hormone without taking steps to decrease it to 'normal' levels) and decreased temporal (circadian) cortisol adjustments. In the brain, sharp increases in beta-endorphin accompany relative decreases in neurotransmitters like norepinephrine and dopamine as a result of stress on the body. These programmed responses serve a vital purpose in assisting the body to respond in a favourable physiologic manner to stressors. In one sense this response is akin to an automobile caught sliding sideways on an icy road (stress on the body); the correct response is to right the direction of the automobile by turning the wheel (hormonal response) into the direction of the slide, thereby averting a crash.

Several theories have been suggested to explain the effects of adaptogenic substances [50]. It has been found that most or all adaptogens are potent antioxidants. Many theories proposed that adaptogens function primarily due to their antioxidant and free radical scavenging effects [51]. However, these theories are partially accurate and inadequate to explain the full effects of adaptogens.

More recent research postulates that adaptogens work primarily by affecting the HPA axis and the sympathoadrenal system (SAS) [52]. Thus, adaptogens modulate the body's response to stress (physical, environmental, or emotional) and help regulate the interconnected endocrine, immune, and nervous systems. This re-regulation of a disordered or highly stressed system is achieved by metabolic regulators such as cytokines, catecholamines, glucocorticoids, cortisol, serotonin, nitric oxide (NO), cholecystokinin, corticotrophin-releasing factor (CRF), and sex hormones. This explains the broad spectrum of activity shown by adaptogens in terms of anti-inflammatory, antioxidant, anxiolytic, antidepressant, nervine, and amphoteric effects. Adaptogens enhance the physiologic stress adaptation, supporting the body in handling the stress of CFS and the many factors that contribute to CFS symptoms. Adaptogens have been studied in a number of clinical situations, and their multiple uses and beneficial effects can be applied with success in the many imbalances suffered by people with CFS.

Some of the herbs used for CFS are discussed below. These herbs are commonly used in various traditional systems of medicine and profound scientific data exists on them.

Cat's Claw (Botanical Name: Uncaria tomentosa (Rubiaceae)) Chemical constituents: Cat's claw contains different alkaloidal constituents (pentacyclic oxindoles (uncarine C and uncarine E) and tetracyclic oxindoles (mitraphylline, rhynchophylline and isorhynchophylline)), quinovic acid glycosides, polyhydroxylated triterpenes, steroidal compounds (beta-sitosterol, stigmasterol, and campesterol), ursolic acid, and oleanolic acid. The inner bark of cat's claw is the main source of medicinal activity although the roots and leaves are also used [53].

Usage: Cat's claw is used as a medicinal herb primarily for immune system stimulation [54]. Cat's claw's immunostimulating properties enhance the function of white blood cells to attack and digest carcinogenic substances and harmful microorganisms that may inhibit the growth of cancer cells and tumours [55-59]. The pentacyclic alkaloids are responsible for the immune-strengthening effects, whereas the tetracyclic oxindole alkaloid rhynchophylline has an antihypertensive property that may be beneficial in preventing the risk of strokes and heart attacks by reducing heart rate, lowering blood pressure, increasing circulation, and lowering blood cholesterol levels [54]. The quinovic acid glycosides isolated from the bark of cat's claw have antiviral activities in vitro against vesicular stomatitis virus. Cat's claw has a healing effect on the digestive system, and good results have been achieved in treating CFS [54]. The anti-inflammatory actions of Cat's claw have been effective in relieving the inflammation and swelling prevalent in arthritis, rheumatism, and joint pain [60-66].

Side-effects: Few side-effects have been reported from using cat's claw in recommended doses. It should not be combined with hormonal drugs, insulin, and vaccines and is contraindicated in those suffering from coagulation disorders, tuberculosis, and autoimmune diseases [67].

Dosage: Standardized root and bark extracts are available in forms of dry extract, crushed bark, capsule, tablet, tea, and tincture. Extracts of cat's claw are often standardized to $4 \%$ alkaloid content for effective results. Dosages of commercial preparations range from 250 to $1000 \mathrm{mg}$ daily.

\section{Ginseng (Botanical Name: Panax ginseng (Araliaceae))}

Panax ginseng C. A. Mey. Araliaceae is the most popular species of ginseng among the several known species [68]. The other important species are Panax japonicus C. A. Mey. (Panax pseudoginseng Wall. Var, Araliaceae) - the Japanese ginseng - and Panax quinquefolius L. (Araliaceae) - the American ginseng.

Chemical constituents: The dried roots and rhizomes of ginseng contain a number of active constituents including alkaloids, phenolic compounds, flavonoids, terpenes, and triterpenes. However, ginsenosides are usually considered the main constituents to the therapeutic effect of ginseng. Ginsenosides are a class of steroid-like compounds, a family of triterpenoid saponins. The percentage of ginsenoside in ginseng roots determines potency [69]. At least 22 saponins (ginsenosides or panaxosides) have been isolated and found to be the most active constituents, with important ones being Ginsenoside Rg1 and Ginsenoside Rb1 [68]. 
Usage: Ginsenoside Rb1 has a weak anti-inflammatory activity, an antihaemolytic action, and increases gastrointestinal motility [70-73]. Ginsenoside Rg1 has shown weak CNS stimulant activity, anti-fatigue action, and an increase in motor activity [74]. Other active compounds in the root include acetylenic compounds, peptide glycans, polysaccharides, pyran derivatives, and flavones. A fraction of the polyacetylenes called panaxynol has been shown to have cytotoxic effects on some cancer cells in the laboratory [75]. Other constituents include the panaxans which may help lower blood sugar [76].

For centuries, $P$. ginseng has been used for fatigue in oriental folk medicine [77]. It is used primarily to improve psychologic function, exercise performance, immune function, circulation, and blood supply, and to revitalize and aid recovery from weakness after illness [78]. Ginseng is protective in heart as well as other forms of cardiovascular disease. It has antioxidant effects and increases immune system activity [79]. In mice, treatment with ginseng in drinking water for 16-18 days provided effective adaptation to fatigue and increased endurance.

Side-effects: Adverse reactions to high-quality, standardized ginseng preparations are uncommon and usually minor [80]. Long-term use of ginseng may cause menstrual abnormalities and breast tenderness as well as show estrogen-like activity resulting in mastalgia and postmenopausal bleeding in women. Ginseng may also exhibit a hypoglycaemic effect and should be taken with food. Ginseng should not be combined with anticoagulants or with nonsteroidal anti-inflammatory drugs that tend to cause bleeding. Consuming caffeine with ginseng increases the risk of overstimulation and gastrointestinal upset. Ginseng should not be taken by people who have hypertension. Ginseng should be discontinued at least 7 days prior to surgery.

Dosage: Ginseng can be purchased readily as a whole root (dried, peeled), a dried powder, or a standardized extract. Standardized $P$. ginseng contains $4-5 \%$ ginsenosides [76]. As an anti-stress/anti-fatigue agent, 200-600 $\mathrm{mg} /$ day of standardized extract, preferably in divided doses, or $0.5-2 \mathrm{mg} /$ day of powdered root is taken. Ginseng is commonly taken for long periods.

\section{Siberian Ginseng (Botanical Name: Eleutherococcus senticosus (Araliaceae))}

Chemical constituents: One of the better-researched adaptogens, Siberian ginseng contains triterpene saponins, i.e. the eleutherosides similar to ginsenosides that have effects in the body conforming to its definition as an adaptogen [81]. Specifically, six Eleutherococcus compounds exert adaptogenic effects in the body; four of them act as antioxidants, four exhibit anticancer effects, and two show demonstrable immunostimulatory effects $[82,83]$.
Usage: Siberian ginseng has been shown to increase lymphocyte counts and phagocytic indices and exhibits anti-inflammatory, protein-storing, and stimulative effects on the pituitary-adrenal hormone system. Additionally, it demonstrates antiviral effects on several different viruses. In other areas of stress adaptation, Siberian ginseng was able to prolong the swimming time in laboratory animals and altered the profile of HPA axis hormones in animals exposed to extreme environmental conditions. A review of the literature on this herb [84] suggests an ability of the herb to improve mental performance, accommodation to adverse physical conditions, and work quality in the stressful environs of subjects aged 19-72 years. The immunostimulatory, antiviral, HPA axis-modulatory and fatiguedelaying effects of Siberian ginseng may serve people with CFS to improve these parameters, thereby alleviating some symptomatology of the syndrome. In a placebo-controlled study in humans [81], it showed moderate benefit in CFS. In another study [85], use of a Siberian ginseng containing a formulation called Ciwujia showed on exercise performance under a constant endurance load of $450 \mathrm{~kg} \times \mathrm{m} / \mathrm{min}$ $(75 \mathrm{~W})$ that the preparation could increase oxygen uptake, spare the glycogen in muscle, and improve the exercise endurance and work performance in humans. Siberian ginseng can provide adjunctive therapy in CFS with little or no side-effects [80].

Dosage: The standardized extract of Siberian ginseng comes from the dried root containing $1 \%$ eleutheroside $\mathrm{E}$ and is taken three times daily. Products should be standardized to contain at least $0.8 \%$ eleutherosides (the active ingredients). For stress, $100-200 \mathrm{mg}$ three times a day is the recommended dose. For fatigue (and CFS), female infertility, Alzheimer's disease, and fibromyalgia, 100-300 mg twice a day for 60 to 90 days is advised, and then a seven-day break should be taken before resuming treatment.

\section{Caterpillar fungus (Botanical Name: Cordyceps sinensis (Clavicipitaceae))}

Cordyceps sinensis is an entomopathogenic fungus widely used both in clinical medicine and as a household remedy. C. sinensis was first recorded in Tibet in the 15th century and was commonly known as caterpillar fungus; it is considered a medicinal mushroom in oriental medicines [86].

Chemical constituents: Cordycepin, or 3'-deoxyadenosine, a derivative of the nucleoside adenosine is an important constituent and was the initial source of cyclosporine, an immunosuppressant $[87,88]$.

Usage: $C$. sinensis, one of the most valuable medicinal herbs in Traditional Chinese Medicine (TCM), has an extensive history of use in the treatment of mental and physical exhaustion and is often used as a rejuvenative for increasing energy while recovering from serious ill- 
nesses [89-91]. It is also known to be used regularly in the treatment of patients with leukaemia, heart, liver, and kidney problems [92-94]. Additionally, it is known to strengthen the immune system and is used as a treatment against respiratory ailments such as asthma, bronchitis, cough, and lung infections [95]. It is believed to be highly effective against impotence and is extensively used in China as an aphrodisiac. It is also known to relieve pain and to be effective in the treatment of arthritis, spasms, and cramps [96]. It is believed that the herb helps reduce cholesterol levels in the body, assists in digestion, and improves appetite [97]. An experiment with mice noted that C. sinensis may have an antidepressant effect. Researchers have reported cordyceps to have a hypoglycaemic effect and to be beneficial for people with insulin resistance [98].

Patented products: CordyMax CS-4 is a caterpillar fungus derivative produced by a proprietary fermentation process using the mycelia of Paecilomyces hepiali Chen, originally isolated from caterpillar fungus and grown on a proprietary blend of nutrients in a sterile environment. CordyMax CS-4 is officially recognized by the Chinese Ministry of Health as the fermented strain of cordyceps, showing the scientifically supported benefits most similar to the rare and protected natural C. sinensis mushroom.

Dosage: The usual therapeutic dosage for caterpillar fungus (Cordyceps Mycelia (CS-4)) is 750-3000 mg per day (consumed early in the day in order to avoid overstimulation at night). Caterpillar fungus is available in the form of i) $300 \mathrm{mg}$ capsules (combined with $50 \mathrm{mg}$ of Siberian ginseng), ii) 400-750 mg capsules, and iii) $500 \mathrm{mg}$ tablets. Loose caterpillar fungus powder standardized to contain $7 \%$ cordyceptic acid is also available.

\section{Ashwagandha (Botanical Name: Withania somnifera L. Dunal (Solanaceae))}

Withania somnifera L. Dunal belongs to the family Solanaceae. In Ayurveda, ashwagandha is considered a Rasayana herb, which acts as an adaptogen to normalize physiological function by working on the HPA axis and the neuroendocrine system on a non-specific basis to increase health and longevity [99]. The plant parts used are the roots and leaves.

Chemical constituents: The major constituents of ashwagandha are alkaloids and steroidal lactones. Withanine is the main alkaloid, a few others being somniferine, somnine, somniferinine, withananine, and anaferine. The leaves contain steroidal lactones, which are commonly called 'withanolides'. The withanolides have a C28 steroidal nucleus with a C9 side chain, consisting of a sixmembered lactone ring. Withanolides include withaferin, withaferine A, and withanolides E-M [100, 101].

Usage: Ashwagandha has been researched extensively for its potential as an adaptogen and has a well-proven immunomodulatory action. The anti-stress activity of the root of $W$. somnifera has been reported in multiple clinical studies. Glycowithanolides and sitoindosides IX and X are responsible for the immunomodulatory activity. The withanolides, sitoindosides, and withaferine $\mathrm{A}$ of $W$. somnifera are responsible for its antioxidant activity [102-105].

Side-effects: No significant side-effects or known drug interactions have been reported with ashwagandha. It is contraindicated in conjunction with sedatives or anxiolytics or if one is suffering from stomach ulcers. Patients with hyperthyroidism should also avoid the herb since animal studies suggest that it may raise thyroid hormone levels. It is not recommended for use by pregnant women because large doses of ashwagandha may possess abortifacient properties [106].

Dosage and available forms: The typical dosage of ashwagandha herb is $6 \mathrm{~g}$ of the dried root per day. The herb can be taken in a variety of forms (3-6 g) as follows:

- Capsules: Two $500 \mathrm{mg}$ capsules taken three times per day.

- Tea: One teaspoon of the dried root is steeped in boiling water or milk for $15 \mathrm{~min}$, strained, cooled to make ashwagandha tea, and drunk up to 3 cups per day. The tea may be sweetened with honey to help combat the herb's potent taste, if desired.

- Tincture: One half to three quarters of a teaspoon of ashwagandha tincture is dissolved in half a cup of water and may be taken up to three times per day.

\section{Rosenroot (Botanical Name: Rhodiola rosea \\ (Crassulaceae))}

Chemical constituents: Rhodiola rosea contains a variety of active compounds such as rosavins (rosavin, rosarin, and rosin), rhodioloside, and tyrosol [107]. Other constituents include phenolic antioxidants such as proanthocyanidins, quercetin, gallic acid, chlorogenic acid, and kaempferol. The plant part used is the root.

Usage: $R$. rosea L. (Crassulaceae) is a traditional medicinal plant of Eastern Europe and Asia, used as a CNS stimulant, antidepressant, and anti-fatigue drug [108, 109]. In Russia and Scandinavia, $R$. rosea has been used for centuries to cope with the cold Siberian climate and stressful life. Such effects were provided with evidence in laboratory models of stress using the nematode C. elegans and in rats in which Rhodiola effectively prevented stress-induced changes in appetite, physical activity, weight gain, and the oestrus cycle. A clinical trial showed significant effect for a Rhodiola extract in doses of 340-680 mg per day in male and female patients from 18 to 70 years of age with mild to moderate depression. $R$. rosea extract SHR-5 exerts an anti-fatigue effect that increases mental performance, particularly the ability to concentrate in healthy subjects and in burnout patients with fatigue syndrome [108-110]. Rhodiola in human subjects significantly reduced symptoms of fatigue and improved attention after 4 weeks of 
repeated administration [111]. $R$. rosea may be beneficial to increase energy and mental performance for people suffering from Hashimoto's disease [109, 111].

Side-effects: No side-effects were demonstrated at these doses in the treatment of mild to moderate depression.

Dosage: $R$. rosea extract is mainly used in the form of capsules or tablets ( 1 or 2 daily), though tinctures are also available. The capsules and tablets often contain $100 \mathrm{mg}$ of a standardized amount of 3\% rosavins.

Liquorice (Botanical Name: Glycyrrhiza glabra (Fabaceae)) Liquorice is a versatile and commonly used herb in TCM, Ayurveda, Unani-Tibb, and European herbal traditions as an adaptogen, antihistaminic, anti-inflammatory, antidiuretic, antitussive, antiviral, demulcent, hepatoprotective, and gastroprotective agent [112-114].

Chemical constituents: Liquorice rhizome is rich in flavonoids and isoflavonoids, sterols, triterpenoid saponins, estrogenic substances, and glycyrrhizin. Antiviral phenolic constituents present in root extracts are licopyranocoumarin, licoarylcoumarin, and glisoflavone. Glycyrrhizin, one of the main active ingredients in liquorice, is believed to contribute to the herb's many healing properties. Glycyrrhizin shows anti-inflammatory actions and may inhibit the breakdown of the cortisol produced by the body. Liquorice flavonoids help heal digestive tract cells. They are also potent antioxidants and work to protect liver cells [115].

Usage: Liquorice is an immune amphoteric and can be useful for autoimmune disorders (lupus, scleroderma, Crohn's disease, rheumatoid arthritis) as well as immune deficiency conditions (cancer, HIV, CFS) [116]. It strengthens adrenal function and can be used with $P$. ginseng for Addison's disease. It is also useful for allergies, ulcers, elevated cortisol levels, polycystic ovary syndrome (PCOS) (with Serenoa and Paeonia), and spasmodic coughs [117].

Side-effects: Excessive liquorice administration is known to promote cardiovascular toxicity, hypertension, and oedema. Excess doses of liquorice can have a hyperaldosterogenic effect (increased retention of sodium and excretion of potassium, water retention, and high blood pressure). Women are more sensitive to this effect than men and patients with hypertension should avoid using this herb on a continual basis [118].

Dosage: The necessary dosage is $300 \mathrm{mg}$ three times per day (which is 20-28\% glycyrrhizic acid).

\section{Jiaogulan (Botanical Name: Gynostemma pentaphyllum (Cucurbitaceae))}

This member of the Curcubitaceae family has a long history of use in Southern China and Taiwan as a folk remedy for fatigue, weakness, asthma, hepatitis, migraines, and cancer $[119,120]$. Due to its low cost and safety, it has be- come much more widely used as a 'Ginseng' substitute and adaptogen throughout Southeast Asia and is frequently referred to as 'Southern Ginseng'. Jiaogulan is known for its anti-aging, energy-boosting, antioxidant, and adaptogenic health benefits.

Chemical constituents: Its chemical constituents include the triterpenoid saponins gypenosides which are structurally closely related to the ginsenosides of $P$. ginseng $[119,121]$.

Usage: It is known as an adaptogen and antioxidant that has been found to be effective in regulating blood pressure, lowering cholesterol, and improving endurance [119]. Clinically, jiaogulan is useful for hypertension, congestive heart failure, liver disease, elevated blood lipids, and for strengthening the immune system and inhibiting cancer $[119,121]$. Jiaogulan is also believed to have calming effects and to be useful in combination with the Codonopsis plant for jet lag and altitude sickness.

Dosage: The adaptogenic use of jiaogulan is standardized on an extract containing $85 \%$ gypenosides, with a recommended daily dose of 60-180 mg gypenosides; however, published studies to justify this dose are lacking.

\section{Trichopus zeylanicus (Trichopodaceae)}

Trichopus zeylanicus is a small herbaceous plant growing along the tropical forests in southwestern India, Malaysia, and Ceylon. The Kani, a tribal population in India, traditionally use the seeds of this plant to combat fatigue. In southern India, the plant is called 'Arogya pacha', literally meaning 'the green that gives strength' [122].

Chemical constituents: Leaves of the plant contain flavonoid glycosides, glycolipids, and some other nonsteroidal compounds with profound adaptogenic and immmuno-enhancing properties [123].

Usage: The fruits show mainly anti-fatigue properties. T. zeylanicus treatment enhanced the physical endurance of mice and rats in forced swim tests [124]. The leaf extract (100 mg/kg) of T. zeylanicus, when given to male adult mice, increased their swimming performance and decreased plasma glucose levels. T. zeylanicus whole plant powder has also been found to show anti-fatigue effects in young Sprague-Dawley rats as well as aged normal and mutant Ames dwarf mice when evaluated by subjecting the animals to a forced swim test [125]. Based on the tribal knowledge, the Tropical Botanical Gardens Research Institute (TBGRI), India, was successful in developing a scientifically validated and standardized herbal drug. The drug was named 'Jeevani' and was released for commercial production in 1995 [126]. T. zeylanicus appears to be effective against oxidative stress and may protect against lipid peroxidation and DNA cleavage [127]. 
Table 4. Selected herbs for the treatment of CFS

\begin{tabular}{lll}
\hline Botanical name and plant part & Family & Geographic area where used \\
\hline Acanthopanacis senticosus (root/rhizome) & Araliaceae & East Asia (China, Japan) \\
Aloe barbadensis, A. indica, A. perfoliata, A. vulgaris (herb) & Asphodelaceae & India, Egypt, Australia, Sahara \\
Angelica sinensis (herb) & Apiaceae & East Asia (China) \\
Aralia mandshurica, A. elata, A. schmidtii (roots) & Araliaceae & Russia, China, Korea, Japan \\
Bryonia alba (root) & Cucurbitaceae & Europe, Northern Iran, United States \\
Codonopsis pilosula (Dang Shen root) & Campanulaceae & Northeast Asia, Korea \\
Crataegus oxycantha (herb) & Rosaceae & Africa, Asia, Europe \\
Echinacea purpurea (herb) & Asteraceae & eastern and central North America \\
Eucommia ulmoides (bark) & Eucommiaceae & Europe, North America, East Asia (China) \\
Gentiana lutea (root) & Gentianaceae & Turkey \\
Hoppea dichotoma (root) & Gentianaceae & Asia, Africa \\
Hypericum perforatum (herb) & Clusiaceae & North America, Europe, Turkey, Russia, India, China \\
Matricaria chamomilla (flowers and the whole plant) & Asteraceae & West Asia, Europe, South America \\
Oplopanax elatus, Echinopanax elatus (bark) & Araliaceae & China, Russia, Korea \\
Oryza sativa (cereal) & Poaceae & East Asia \\
Paeonia japonica (herb) & Paeoniaceae & East Asia \\
Pinus pinaster (bark) & Pinaceae & Europe (France) \\
Schisandra chinensis, S. splenathera (Wu Wei Zi berries/seeds) & Schisandraceae & China, Korea, Japan, Russia \\
\hline
\end{tabular}

\section{Holy Basil or Tulsi (Botanical Name: Ocimum sanctum} (Lamiaceae))

Tulsi, or Holy Basil, has a long tradition of use in Ayurveda, Siddha, and the Unani-Tibb systems of medicine and is used as an adaptogen, antibacterial, anticholesteraemic, antidepressant, antioxidant, antiviral, expectorant, and immune amphoteric agent. It is considered a Rasayana or rejuvenative medicine and is traditionally used to improve memory as well as to treat coughs, colds, indigestion, asthma (with black pepper), and fatigue [128, 129].

Chemical constituents: Essential oils of Ocimum sanctum contain a number of polyphenols such as eugenol, carvacrol, nerol, geraniol, estragol, linalool etc. Leaves contain ursolic acid, apigenin-7-O-glucuronide, luteolin7-O-glucuronide and the flavonoids orientin, vicenin, and molludistin. The phytoconstituents of tulsi are powerful antioxidants [130].

Usage: Tulsi is reported to increase physical and mental endurance and to protect animals from physical, chemical, biological, and emotional stress [131, 132]. It exhibits a potent anti-stress property comparable to that of $P$. ginseng [133]. The dried powder of the plant enhanced the physical endurance and survival time of swimming mice and prevented stress-induced gastric ulcers in rats [131]. O. sanctum extracts are found to possess neuroprotective, nootropic, hepatoprotective, hypoglycaemic, antihypertensive, antihyperlipidaemic, antihistaminic, and immunomodulatory activities [133].

Dosage: Holy Basil is generally effective in a single dose of 300-600 mg of dried leaves daily for preventive therapy and $600-1800 \mathrm{mg}$ in divided doses daily for curative therapy.

Guduchi (Botanical Name: Tinospora cordifolia (Menispermaceae))

Chemical constituents: The active adaptogenic constituents are diterpene compounds including tinosporone, tino- sporic acid, cordifolisides A to E, syringen, berberine, and giloin [134-135].

Usage: Tinospora cordifolia (Guduchi) is an important Ayurvedic Rasayana remedy used as an adaptogen, antiinflammatory, antioxidant, hepatoprotective, hypoglycaemic, diuretic, and immune amphoteric agent [136-138]. The stem possesses maximum medicinal activity.

Dosage: $300 \mathrm{mg}$ tablets containing a standardized extract derived from T. cordifolia are available. Two tablets two times a day along with meals with a large glass of water are generally recommended.

\section{Amla or Gooseberry Fruit (Botanical Name:}

Emblica officinalis (Phyllanthaceae))

Amla, or Amalaki, a Rasayana or rejuvenative remedy in Ayurvedic medicine is used as an adaptogen, antioxidant, anticholesteraemic, hypoglycaemic, anti-inflammatory, diuretic, and hepatoprotective agent [139]. Amla is used clinically for connective tissue disorders (scleroderma, rheumatoid arthritis, lupus, ankylosing spondylitis) as well as to build blood (anaemia - use with ashwagandha) and to strengthen bones, capillaries, and the eyes [131]. It also inhibits atherosclerosis and carcinogenesis and may help slow the degeneration caused by Alzheimer's disease. There are no published clinical studies to support dosing. A dose of 3-6 g/day of powdered emblica has been extrapolated from a vitamin C $1 \mathrm{~g} /$ day dose.

\section{Dioscorea species (Dioscoreaceae)}

Dioscorea villosa (wild yam), Dioscorea transversa, Dioscorea dregeana, Dioscorea pentaphyla (Kanta-aloo), Dioscorea fasciculata (soosni-aloo), and Dioscorea purpurea (sweet potato) are some of the various species of Dioscorea useful in chronic fatigue. The plant is also cited with contraceptive, antispasmodic, anti-inflammatory, antioxidant, hepatoprotective, and cardiovascular activities. The activity of Dioscorea species has been attributed 
to the action of various steroidal saponins (diosgenin and aglycone) and also to dioscorin(e), dioscin(e), and other alkaloids derived from nicotinic acid [140].

\section{Miscellaneous Herbal Drugs with Possible Adaptogenic Activity}

Mimosa flowers or stem bark (Albizia julibrissin), saw palmetto berries (Serenoa repens), Eucommia bark (Eucommia ulmoides), suma bark (Pfaffia paniculata), reishi fungus (Ganoderma lucidum), Shatavari (Asparagus racemosus), Prince Seng root (Pseudostellaria heterophylla) and Huang Qi (Astragalus membranaceus) are some of the herbal drugs which are mild adaptogens and hence active against CFS. Some additional herbs which are used for the treatment of CFS are mentioned in table 4 .

\section{Conclusion}

CFS is a common lifestyle disease which is characterized by a wide spectrum of symptoms and causes. It may also coexist with other diseases such as multiple sclerosis, Parkinson's disease, depression, cancer, HIV infection etc. Several botanical therapies from various folkloric and traditional medicine systems may be used in the treatment of CFS because of their ready acceptance, safety, negligible toxicity, and effectiveness. The botanical therapies discussed above are very commonly used drugs and profound data exists on their usage. However, there could be more such plant drugs which lack in sound scientific data and hence are not discussed here. Thus, a systematic approach of drug development, including identification of phytoconstituents and their pharmacology, as well as preclinical and clinical studies of these plants to develop effective and safe treatment are required.

\section{Disclosure Statement}

There is no conflict of interest regarding this manuscript.

\section{References}

1 Fukuda K, Straus SE, Hickie I, Sharpe MC, Dobbins JG, Komaroff A: The chronic fatigue syndrome: a comprehensive approach to its definition and study. Ann Intern Med 1994;121:953-959.

2 Papanicolaou DA, Amsterdam JD, Levine S, McCann SM, Moore RC, Newbrand $\mathrm{CH}$ Allen G, Nisenbaum R, Pfaff DW, Tsokos GC, Vgontzas AN, Kales A: Neuroendocrine aspects of chronic fatigue syndrome. Neuroimmunomodulation 2004;11:65-74.

3 Jason LA, Richman JA, Rademaker AW, Jordan KM, Plioplys AV, Taylor RR, McCready W, Huang CF, Plioplys S: A community-based study of Chronic Fatigue Syndrome. Arch Intern Med 1999;159:2129-2137.

4 Holmes GP, Kaplan JE, Gantz NM, Komaroff AL, Schonberger LB, Straus SE, Jones JF, Dubois RE, Cunningham-Rundles C, Pahwa S: Chronic fatigue syndrome: a working case definition. Ann Intern Med 1988;108:387-389.

5 Richman JA, Flaherty JA, Rospenda KM: Chronic fatigue syndrome: have flawed assumptions been derived from treatment-based studies? Am J Public Health 1994;84:282-284.

6 Fukuda K, Dobbins JG, Wilson LJ, Dunn RA Wilcox K, Smallwood D: An epidemiologic study of fatigue with relevance for the chronic fatigue syndrome. J Psychiatr Res 1997;31:19 29.

7 Chronic Fatigue Syndrome. US Department of Health and Human Services, Public Health Service, US Centers for Disease Control and Prevention (CDC), National Center for Infectious Disease, Atlanta, GA, 1998.
$>$ Jordan KM, Landis DA, Downey MC, Osterman SL, Thurm AE, Jason LA: Chronic fatigue syndrome in children and adolescents: a review. J Adolesc Health 1998;22:4-18.

$\checkmark 9$ Reyes M, Gary HE Jr, Dobbins JG, Randall B, Steele L, Fukuda K, Holmes GP, Connell DG, Mawle AC, Schmid DS, Stewart JA, Schonberger LB, Gunn WJ, Reeves WC: Surveillance for chronic fatigue syndrome - four US cities, September 1989 through August 1993. MMWR CDC Surveill Summ 1997;46:1-13.

10 Buchwald D, Umali P, Umali J, Kith P, Pearlman T, Komaroff AL: Chronic fatigue and the chronic fatigue syndrome in a Pacific Northwest health care system. Ann Intern Med 1995;123:81-88.

11 Afari N, Buchwald D: Chronic Fatigue Syndrome: a review. Am J Psychiatry 2003;160: 221-236.

12 Karlsen K, Larsen JP, Tandberg E, Jorgensen K: Fatigue in patients with Parkinson's disease. Mov Disord 1999;14:237-241.

13 Racke MK, Hawker K, Frohman EM: Fatigue in multiple sclerosis: is the picture getting simpler or more complex? Arch Neurol 2004; 61:176-177.

14 Kent-Braun JA, Miller RG: Central fatigue during isometric exercise in amyotrophic lateral sclerosis. Muscle Nerve 2000;23:909914.

15 Allman BL, Rice CL: Neuromuscular fatigue and aging: central and peripheral factors. Muscle Nerve 2002;25:785-796.

16 Henderson M, Tannock C: Objective assessment of personality disorder in chronic fatigue syndrome. J Psychosom Res 2004;56:251-254.
17 Manzullo E, Liu W, Escalante C: Treatment for cancer-related fatigue: an update. Expert Rev Anticancer Ther 2003;3:99-106.

18 Sullivan PS, Dworkin MS: Adult and adolescent spectrum of HIV disease investigators. Prevalence and correlates of fatigue among persons with HIV infection. J Pain Symptom Manage 2003;25:329-333.

19 de Lange FP, Kalkman JS, Bleijenberg G, Hagoort P, van der Meer JW, Toni I: Gray matter volume reduction in the chronic fatigue syndrome. Neuroimage 2005;26:777-781.

20 de Lange FP, Kalkman JS, Bleijenberg G, Hagoort P, van der Werf SP, van der Meer JW, Toni I: Neural correlates of the chronic fatigue syndrome: an fMRI study. Brain 2004; 127:1948-1957.

-21 Lange G, Steffener TJ, Cook DB, Bly BM, Christodoulou C, Liu WC, Deluca J, Natelson BH: Objective evidence of cognitive complaints in Chronic Fatigue Syndrome: a BOLD fMRI study of verbal working memory. Neuroimage 2005;26:513-524.

22 Siemionow V, Fang Y, Calabrese L, Sahgal V, Yue GH: Altered central nervous system signal during motor performance in chronic fatigue syndrome. Clin Neurophysiol 2004;115:23722381.

23 Schillings ML, Kalkman JS, van der Werf SP, van Engelen BG, Bleijenberg G, Zwarts MJ: Diminished central activation during maximal voluntary contraction in chronic fatigue syndrome. Clin Neurophysiol 2004;115:25182524. 
-24 Cleare AJ, Messa C, Rabiner EA, Grasby PM: Brain 5-HT1A receptor binding in chronic fatigue syndrome measured using positron emission tomography and [11C]WAY-100635. Biol Psychiatry 2005;57:239-246.

25 Yamamoto S, Ouchi Y, Onoe H, Yoshikawa E Tsukada H, Takahashi H, Iwase M, Yamaguti K, Kuratsune H, Watanabe Y: Reduction of serotonin transporters of patients with chronic fatigue syndrome. Neuroreport 2004;15:25712574.

26 Cleare AJ: The neuroendocrinology of chronic fatigue syndrome. Endocr Rev 2003;24:236252.

27 Di Giorgio A, Hudson M, Jerjes W, Cleare AJ: 24-hour pituitary and adrenal hormone profiles in chronic fatigue syndrome. Psychosom Med 2005;67:433-440.

28 Crofford LJ, Young EA, Engleberg NC, Korszun A, Brucksch CB, McClure LA, Brown MB, Demitrack MA: Basal circadian and pulsatile ACTH and cortisol secretion in patients with fibromyalgia and/or chronic fatigue syndrome. Brain Behav Immun 2004;18:314-325.

29 Roberts AD, Wessely S, Chalder T, Papadopoulos A, Cleare AJ: Salivary cortisol response to awakening in chronic fatigue syndrome. Br J Psychiatry 2004;184:136-141.

\$3 Gaab J, Engert V, Heitz V, Schad T, Schürmeyer TH, Ehlert U: Associations between neuroendocrine responses to the Insulin Tolerance Test and patient characteristics in chronic fatigue syndrome. J Psychosom Res 2004;56:419-424.

31 Candy B, Chalder T, Cleare AJ, Peakman A, Skowera A, Wessely S, Weinman J, Zuckerman M, Hotopf M: Predictors of fatigue following the onset of infectious mononucleosis. Psychol Med 2002;33:847855.

-32 Rubin GJ,Hotopf M, Papadopoulos A, Cleare A: Salivary cortisol as a predictor of postoperative fatigue. Psychosom Med 2005;67:441447.

33 Glass JM, Lyden AK, Petzke F, Stein P, Whalen G, Ambrose K, Chrousos G, Clauw DJ: The effect of brief exercise cessation on pain, fatigue, and mood symptom development in healthy, fit individuals. J Psychosom Res 2004;57:391-398.

34 Amel Kashipaz MR, Swinden D, Todd I, Powell RJ: Normal production of inflammatory cytokines in chronic fatigue and fibromyalgia syndromes determined by intracellular cytokine staining in short-term cultured blood mononuclear cells. Clin Exp Immunol 2003;132:360-365.

-35 Tomoda A, Joudoi T, Rabab el-M, Matsumoto T, Park TH, Miike T: Cytokine production and modulation: comparison of patients with chronic fatigue syndrome and normal controls. Psychiatry Res 2005;134:101-104.

-36 Tirelli U, Marotta G, Improta S, Pinto A: Immunological abnormalities in patients with chronic fatigue syndrome. Scand J Immunol 1994;40:601-608.

-37 Caligiuri M, Murray C, Buchwald D, Levine H, Cheney P, Peterson D, Komaroff AL, Ritz J: Phenotypic and functional deficiency of natural killer cells in patients with chronic fatigue syndrome. J Immunol 1987;139:3306-3313.
38 Skowera A, Cleare A, Blair D, Bevis L, Wessely SC, Peakman M: High levels of type 2 cytokine-producing cells in chronic fatigue syndrome. Clin Exp Immunol 2004;135:294302.

39 Wood GC, Bentall RP, Gopfert M, Dewey ME, Edwards RH: The differential response of chronic fatigue, neurotic and muscular dystrophy patients to experimental psychological stress. Psychol Med 1994;24:357-364.

40 Hickie I, Kirk K, Martin N: Unique genetic and environmental determinants of prolonged fatigue: a twin study. Psychol Med 1999; 29:259-268

-41 Farmer A, Scourfield J, Martin N, Cardno A, McGuffin P: Is disabling fatigue in childhood influenced by genes? Psychol Med 1999;29:279-282.

42 Kaushik N, Fear D, Richards SC, McDermott CR, Nuwaysir EF, Kellam P, Harrison TJ, Wilkinson RJ, Tyrrell DA, Holgate ST, Kerr JR: Gene expression in peripheral blood mononuclear cells from patients with chronic fatigue syndrome. J Clin Pathol 2005;58:826-832.

43 Narita M, Nishigami N, Narita N, Yamaguti K, Okado N, Watanabe Y, Kuratsune H: Association between serotonin transporter gene polymorphism and chronic fatigue syndrome. Biochem Biophys Res Commun 2003;311:264-266.

44 Vladutiu GD, Natelson BH: Association of medically unexplained fatigue with ACE insertion/deletion polymorphism in Gulf War veterans. Muscle Nerve 2004;30:38-43.

45 Lloyd A, Hickie I, Wakefield D, Boughton C, Dwyer J: A double-blind, placebo-controlled trial of intravenous immunoglobulin therapy in patients with chronic fatigue syndrome. Am J Med 1990;89:561-568.

46 Strayer DR, Carter WA, Brodsky I, et al: A controlled clinical trial with a specifically configured RNA drug, poly(I):poly(C12U), in chronic fatigue syndrome. Clin Infect Dis 1994;18:S88-S95.

47 Kelly GS: Nutritional and botanical interventions to assist with the adaptation to stress. Altern Med Rev 1999;4:249-265.

48 Chen R, Moriya J, Yamakawa J, Takahashi T, Kanda T: Traditional chinese medicine for chronic fatigue syndrome. Evid Based Complement Alternat Med 2010;7:3-10.

49 Wagner H: Immunostimulants and adaptogens from plants; in Arnason J, Mata R, Romeo J (eds): Phytochemistry of Medicinal Plants. New York, Plenum Press, 1995, pp 1-18.

50 Panossian A, Wikman G: Evidence-based efficacy of adaptogens in fatigue, and molecular mechanisms related to their stress-protective activity. Curr Clin Pharmacol 2009;4:198219.

51 Panossian A: Adaptogens: tonic herbs for fatigue and stress. Alter Compl Ther 2003;9: 327-331.

52 Panossian A, Wagner H: Stimulating effect of adaptogens: an overview with particular reference to their efficacy following single dose administration. Phytother Res 2005;19:819-838.
53 Hemingway SR, Phillipson JD: Alkaloids from South American species of Uncaria (Rubiaceae). J Pharm Pharmacol 1974;26 (suppl):113P.

54 Erowele G, Kalejaiye AO: Pharmacology and therapeutic uses of cat's claw. Am J Health Syst Pharm 2009;66:992-995.

55 Reis SR, Valente LM, Sampaio AL, Siani AC, Gandini M, Azeredo EL, D’Avila LA Mazzei JL, Henriques MG, Kubelka CF Immunomodulating and antiviral activities of Uncaria tomentosa on human monocytes infected with Dengue Virus-2. Int Immunopharmacol 2008;8:468-476.

56 Spelman K, Burns J, Nichols D, Winters N, Ottersberg S, Tenborg M: Modulation of cytokine expression by traditional medicines: a review of herbal immunomodulators. Altern Med Rev 2006;11:128-150.

57 Eberlin S, Santos LM, Queiroz ML: Uncaria tomentosa extract increases the number of myeloid progenitor cells in the bone marrow of mice infected with Listeria monocytogenes. Int Immunopharmacol 2005;5:1235-1246.

58 Sheng Y, Pero RW, Wagner H: Treatment of chemotherapy-induced leukopenia in a rat model with aqueous extract from Uncaria tomentosa. Phytomedicine 2000;7:137-143.

59 Pilarski R, Filip B, Wietrzyk J, Kuraś M, Gulewicz K: Anticancer activity of the Uncaria tomentosa (Willd.) DC. preparations with different oxindole alkaloid composition. Phytomedicine 2010;17:1133-1139.

-60 Sandoval M, Charbonnet RM, Okuhama NN, Roberts J, Krenova Z, Trentacosti AM, Miller MJ: Cat's claw inhibits TNF-alpha production and scavenges free radicals: role in cytoprotection. Free Radic Biol Med 2000;29:71-78.

61 AguilarJL, Rojas P, Marcelo A, Plaza A, Bauer R, Reininger E, Klaas CA, Merfort I: Antiinflammatory activity of two different extracts of Uncaria tomentosa (Rubiaceae). J Ethnopharmacol 2002;81:271-276.

62 Allen-Hall L, Arnason JT, Cano P, Lafrenie RM Uncaria tomentosa acts as a potent TNF-alpha inhibitor through NF-kappaB. J Ethnopharmacol 2009;127:685-693.

63 Zeng K, Thompson KE, Yates CR, Miller DD: Synthesis and biological evaluation of quinic acid derivatives as anti-inflammatory agents. Bioorg Med Chem Lett 2009;19:5458-5460.

64 Yuan D, Ma B, Yang JY, Xie YY, Wang L, Zhang LJ, Kano Y, Wu CF: Anti-inflammatory effects of rhynchophylline and isorhynchophylline in mouse N9 microglial cells and the molecular mechanism. Int Immunopharmacol 2009;9:1549-1554.

65 Pero R: Method of preparation and composition of a water soluble extract of the bioactive component of the plant species Uncaria for enhancing immune, anti-inflammatory, anti-tumor and DNA repair processes of warm blooded animals. United States Patent No. 7.595.064. September 29, 2009.

-66 Mur E, Hartig F, Eibl G, Schirmer M: Randomized double blind trial of an extract from the pentacyclic alkaloid-chemotype of uncaria tomentosa for the treatment of rheumatoid arthritis. J Rheumatol 2002;29:678-681. 
67 Brinckmann JA, Wollschlaeger B: Cat Claw; in Mark B (ed): The ABC Clinical Guide to Herbs, ed 1. American Botanical Council, Texas, Thieme, 2003, pp 26-33.

68 Lee J, Yuqing Z: Current evaluation of the millennium phytomedicine - ginseng (I): etymology, pharmacognosy, phytochemistry, market and regulations. Curr Med Chem 2009;16:2475-2484.

69 Duke JA: CRC Handbook of Medicinal Herbs. Boca Raton, FL, CRC Press, 1985, pp 340-341.

70 Park J, Cho JY: Anti-inflammatory effects of ginsenosides from Panax ginseng and their structural analogs. Afr J Biotechnol 2009;8:3682-3690.

71 Kim HA, Kim S, Chang SH, Hwang HJ, Choi YN: Anti-arthritic effect of ginsenoside $\mathrm{Rb} 1$ on collagen induced arthritis in mice. Int Immunopharmacol 2007;7:1286-1291.

72 Lee JG, Lee YY, Wu B, Kim SY, Lee YJ, Yun-Choi HS, Park JH: Inhibitory activity of ginsenosides isolated from processed ginseng on platelet aggregation. Pharmazie 2010;65:520-522.

73 Kim Yu A, Akoev VR, Elemesov RE: Hyperosmotic hemolysis and antihemolytic activity of the saponin fraction and triterpene glycosides from Panax ginseng C. A. Meyer. Membr Cell Biol 2000;14:237-251.

74 Lian XY, Zhang Z, Stringer JL: Protective effects of ginseng components in a rodent model of neurodegeneration. Ann Neurol 2005;57:642-648.

75 Chang YS, Seo EK, Gyllenhaal C, Block KI: Panax ginseng: a role in cancer therapy? Integr Cancer Ther 2003;2:13-33.

76 Jia L, Zhao Y, Liang XJ: Current evaluation of the millennium phytomedicine - ginseng (II): collected chemical entities, modern pharmacology, and clinical applications emanated from traditional Chinese medicine. Curr Med Chem 2009;16:2924-2942.

77 Dubick MA: Historical perspectives on the use of herbal preparations to promote health. J Nutr 1986;116:1348-1354.

78 Banerjee U, Izquierdo JA: Antistress and antifatigue properties of Panax ginseng: comparison with piracetam. Acta Physiol Lat Am 1982;32:277-285.

79 Chu SF, Zhang JT: New achievements in ginseng research and its future prospects. Chin J Integr Med 2009;15:403-408.

80 Mahady GB, Gyllenhaal C, Fong HHS, et al: Ginsengs: a review of safety and efficacy. Nutr Clin Care 2000;3:90-101.

81 Hartz AJ, Bentler S, Noyes R, Hoehns J, Logemann C, Sinift S, Butani Y, Wang W, Brake K, Ernst M, Kautzman H: Randomized controlled trial of Siberian ginseng for chronic fatigue. Psychol Med 2004;34:51-61.

82 Li XC, Barnes DL, Khan IA: A new lignan glycoside from Eleutherococcus senticosus. Planta Med 2001;67:776-778.

83 CT Horng, IM Liu, DH Kuo, et al: Comparison of xanthine oxidase-inhibiting and free radical-scavenging activities between plant adaptogens of Eleutherococcus senticosus and Rhodiola rosea. Drug Dev Res 2010;71:249252.
-84 Kuo J, Chen KWC, Cheng IS, Tsai PH, Lu YJ, Lee NY: The effect of eight weeks of supplementation with Eleutherococcus senticosus on endurance capacity and metabolism. Human Chin J Physiol 2010;53:105-111.

85 Wu Y, Wang X, Li M, Compbell TC: Effect of Ciwujia (Radix Acanthopanacis senticosus) preparation on exercise performance under constant endurance load for elderly. Wei Sheng Yan Jiu 1998;27:421-424.

86 Winkler D: Yartsa Gunbu (Cordyceps sinensis) and the fungal commodification of the rural economy in Tibet AR. Economic Botany 2008;62:291-305.

87 Holliday J, Cleaver M: Medicinal value of the caterpillar fungi species of the genus Cordyceps (Fr.) Link (Ascomycetes). A review. Int J Med Mushrooms 2008;10:219-234.

-88 Yu R, Wang L, Zhang H, Zhou C, Zhao Y: Isolation, purification and identification of polysaccharides from cultured Cordyceps militaris. Fitoterapia 2004;75:662-666.

89 Esteban CI: Cordyceps sinensis, a fungi used in the Chinese traditional medicine. Rev Iberoam Micol 2007;24:259-262.

90 Koh JH, Kim KM, Kim JM, Song JC, Suh HJ: Antifatigue and antistress effect of the hot-water fraction from mycelia of Cordyceps sinensis. Biol Pharm Bull 2003;26:691-694.

-91 Ng TB, Wang HX: Pharmacological actions of Cordyceps, a prized folk medicine. J Pharm Pharmacol 2005;57:1509-1519.

$\checkmark 92$ Zhou X, Gong Z, Su Y, Lin J, Tang K: Cordyceps fungi: natural products, pharmacological functions and developmental products. J Pharm Pharmacol 2009;61:279-291.

-93 Zhu JS, Halpern GM, Jones K: The scientific rediscovery of an ancient Chinese herbal medicine: Cordyceps sinensis: part I. J Altern Complement Med 1998;4:289-303.

94 Zhu JS, Halpern GM, Jones K: The scientific rediscovery of a precious ancient Chinese herbal regimen: Cordyceps sinensis: part II. J Altern Complement Med 1998;4:429-457.

95 Gong XJ, Ji H, Lu SG, et al: Effects of polysac charides from cultured Cordyceps sinensis on murine immunologic function. J China Pharm Univ 2000;31:53.

96 Li SP, Li P, Dong TT, Tsim KW: Anti-oxidation activity of different types of natural Cordyceps sinensis and cultured Cordyceps mycelia. Phytomedicine 2001;8:207-212.

-97 Paterson RR: Cordyceps: a traditional Chinese medicine and another fungal therapeutic biofactory? Phytochemistry 2008;69:14691495.

98 Zhang G, Huang Y, Bian Y, Wong JH, $\mathrm{Ng}$ TB, Wang H: Hypoglycemic activity of the fungi Cordyceps militaris, Cordyceps sinensis, Tricholoma mongolicum, and Omphalia lapidescens in streptozotocin-induced diabetic rats. Appl Microbiol Biotechnol 2006;72:1152-1156

99 Tharakan B, Manyam BV: Botanical therapies in chronic fatigue. Phytother Res 2006;20:9195.
100 Mirjalili MH, Moyano E, Bonfill M, Cusido RM, Palazón J: Steroidal lactones from Withania somnifera, an ancient plant for novel medicine. Molecules 2009;14:2373-2393.

101 Winters M: Ancient medicine, modern use: Withania somnifera and its potential role in integrative oncology. Altern Med Rev 2006;11:269-277.

102 Ven Murthy MR, Ranjekar PK, Ramassamy C, Deshpande M: Scientific basis for the use of Indian ayurvedic medicinal plants in the treatment of neurodegenerative disorders: ashwagandha. Cent Nerv Syst Agents Med Chem 2010;10:238-246.

103 Grandhi A, Mujumdar AM, Patwardhan B A comparative pharmacological investigation of Ashwagandha and Ginseng. J Ethnopharmacol 1994;44:131-135.

104 Kulkarni SK, Dhir A: Withania somnifera: an Indian ginseng. Prog Neuropsychopharmacol Biol Psychiatry 2008;32:1093-1105.

105 Scartezzini P, Speroni E: Review on some plants of Indian traditional medicine with antioxidant activity. J Ethnopharmacol 2000; $71: 23-43$.

106 Mishra LC, Singh BB, Dagenais S: Scientific basis for the therapeutic use of Withania somnifera (ashwagandha): a review. Altern Med Rev 2000;5:334-346.

107 Panossian A, Wikman G, Sarris J: Rosenroot (Rhodiola rosea): traditional use, chemical composition, pharmacology and clinical efficacy. Phytomedicine 2010;17:481-493.

108 Darbinyan V, Kteyan A, Panossian A, Gabrielian E, Wikman G, Wagner H: Rhodiola rosea in stress induced fatigue - a double blind cross-over study of a standardized extract SHR-5 with a repeated low-dose regimen on the mental performance of healthy physicians during night duty. Phytomedicine 2000;7:365-371.

109 Kelly GS: Rhodiola rosea: a possible plant adaptogen. Altern Med Rev 2001;6:293-302.

110 Olsson EMG, Schéele B, Panossian AG: A randomized double-blind placebo controlled parallel group study of SHR-5 extract of Rhodiola rosea. Planta Med 2009;75:105-112.

111 Shevtsov VA, Zholus BI, Shervarly VI, Vol'skij VB, Korovin YP, Khristich MP, Roslyakova NA, Wikman G: A randomized trial of two different doses of a SHR-5 Rhodiola rosea extract versus placebo and control of capacity for mental work. Phytomedicine 2003;10:95-105.

112 Isbrucker RA, Burdock GA: Risk and safety assessment on the consumption of Licorice root (Glycyrrhiza sp.), its extract and powder as a food ingredient, with emphasis on the pharmacology and toxicology of glycyrrhizin. Regul Toxicol Pharmacol 2006;46:167-192.

113 Luper S: A review of plants used in the treatment of liver disease: part two. Altern Med Rev 1999;4:178-188.

114 Fiore C, Eisenhut M, Krausse R, Ragazzi E, Pellati D, Armanini D, Bielenberg J: Antiviral effects of Glycyrrhiza species. Phytother Res 2008;22:141-148.

115 Zhang Q, Ye M: Chemical analysis of the Chinese herbal medicine Gan-Cao (licorice). J Chromatogr A 2009;1216:1954-1969. 
116 Brown D: Licorice root-potential early intervention for chronic fatigue syndrome. Quarterly Rev Nat Med 1996;95-96.

117 Stewart PM, Wallace AM, Valentino R, Burt D, Shackleton CH, Edwards CR: Mineralocorticoid activity of licorice: 11-beta-hydroxysteroid dehydrogenase deficiency comes of age. Lancet 1987;330:821-824.

118 Størmer FC, Reistad R, Alexander J: Glycyrrhizic acid in liquorice - evaluation of health hazard. Food Chem Toxicol 1993;31:303-312.

119 Naumovski VR, Huang THW, Tran VH, et al: Chemistry and pharmacology of Gynostemma pentaphyllum. Phytochem Rev 2005;4:197219.

120 Chi AP, Chen JP, Wang ZZ, et al: Morphological and structural characterization of a polysaccharide from Gynostemma pentaphyllum Makino and its anti-exercise fatigue activity. Carbohydrate Polymers 2008;74:868-874.

121 Shen HW, Xiao YC, Che RG, Jin FX, Yu HS Research progress on the chemical ingredients of Gynostemma pentaphyllum. Lishizhen Medicine and Materia Medica Research en.cnki.com.cn/Article_en/CJFDTOTAL-SZ GY200807008.htm.

122 Pushpangadan P, Rajasekharan S, Rathesh Kumar PK, et al: Arogyapacha (Trichopus zeylanicus Gaertn), the ginseng of Kani tribes of Agasthyar hills (Kerala) for ever green health and vitality. Ancient Sci Life 1988;7:13-16.

123 Singh B, Gupta DK, Chandan BK: Adaptogenic activity of a glyco-peptido-lipid fraction from the alcoholic extract of Trichopus zeylanicus Gaertn. Phytomedicine 2001;8:283-291.
124 Evans DA, Subramoniam A, Rajasekharan S, Pushpangadan P: Effect of Trichopus zeylanicus leaf extract on energy metabolism in mice during exercise and at rest. Indian J Pharmacol 2002;34:32-37.

125 Tharakan B, Dhanasekaran M, Brown-Borg HM, Manyam BV: Trichopus zeylanicus combats fatigue without amphetamine-mimetic activity. Phytother Res 2006;20:165-168.

126 Anuradha RV: Mainstreaming indigenous knowledge: developing 'Jeevani'. Economic and Political Weekly 1998;33:1615-1619.

127 Tharakan B, Dhanasekaran M, Manyam BV: Antioxidant and DNA protecting properties of anti-fatigue herb Trichopus zeylanicus. Phytother Res 2005;19:669-673.

128 Mondal S, Mirdha BR, Mahapatra SC: The science behind sacredness of Tulsi (Ocimum sanctum Linn.). Indian J Physiol Pharmacol 2009;53:291-306.

129 Gupta SK, Prakash J, Srivastava S: Validation of traditional claim of Tulsi, Ocimum sanctum Linn. as a medicinal plant. Indian J Exp Biol 2002;40:765-73.

130 Gupta P, Yadav DK, Siripurapu KB, Palit G, Maurya R: Constituents of Ocimum sanctum with antistress activity. J Nat Prod 2007; 70:1410-1416.

131 Pattanayak P, Behera P, Das D, Panda SK: Ocimum sanctum Linn. A reservoir plant for therapeutic applications: an overview. Pharmacogn Rev 2010;4:95-105.

132 Bhargava KP, Singh N: Anti-stress activity of Ocimum sanctum Linn. Indian J Med Res 1981;73:443-451.
133 Singh V, Amdekar S, Verma O: Ocimum sanctum (tulsi): bio-pharmacological activities. WebmedCentral Pharmacol 2010;1: WMC001046.

134 Ahmad F, Ali M, Alam P: New phytoconstituents from the stem bark of Tinospora cordifolia Miers. Nat Prod Res 2010;24:926-934.

135 Singh SS, Pandey SC, Srivastava S, et al Chemistry and medicinal properties of Tinospora cordifolia (guduchi). Ind J Pharmacol 2003;35:83-91.

136 Panchabhai TS, Kulkarni UP, Rege NN: Validation of therapeutic claims of Tinospora cordifolia: a review. Phytother Res 2008;22:425441.

137 Upadhyay AK, Kumar K, Kumar A, Mishra HS: Tinospora cordifolia (Willd.) Hook. f. and Thoms. (Guduchi) - validation of the Ayurvedic pharmacology through experimental and clinical studies. Int J Ayurveda Res 2010;1:112-121.

138 Savrikar SS, Dole V, Ravishankar B, Shukla VJ: A comparative pharmacological investigation of three samples of 'Guduchi ghrita' for adaptogenic activity against forced swimming induced gastric ulceration and hematological changes in albino rats. Int J Ayurveda Res 2010;1:67-72.

139 Krishnaveni M, Mirunalini S: Therapeutic potential of Phyllanthus emblica (amla): the ayurvedic wonder. J Basic Clin Physiol Pharmacol 2010;21:93-105.

140 Sautour M, Offer AC, Dubois MAL: The Dioscorea genus: a review of bioactive steroid saponins. J Nat Med 2007;61:91-101. 